\title{
Communication
}

\section{Protein and Energy Intake of Adult Hospitalized Patients*}

\author{
Abdulrahman Obaid MUSAIGER $^{1}$ and Vichai TANPHAICHITR ${ }^{2}$ \\ ${ }^{1}$ Nutrition Unit, Ministry of Health, Directorate of \\ Public Health, Manama, Bahrain \\ ${ }^{2}$ Division of Nutrition and Biochemical Medicine, Department of Medicine \\ and Ramathibodi Research Center, Faculty of Medicine, \\ Ramathibodi Hospital, Mahidol University, \\ Bangkok
}

(Received May 7, 1983)

Key Words energy intake, protein intake, hospital malnutrition

Good nutrition is essential for the improvement of patients' health and their recovery from injury or illness. The prevalence of protein-energy malnutrition has been observed in hospitalized patients $(1,2)$. The importance of providing comprehensive nutritional care for patients to prevent the incidence of malnutrition among them was emphasized $(3,4)$.

Clinical survey in Thailand indicates that more than $60 \%$ of hospitalized patients suffer from protein-energy malnutrition. It was concluded that the energy status of these patients showed more depletion than their protein status(2). The present study, therefore, was conducted as a pilot study to assess the protein and energy intake of hospitalized patients at Ramathibodi Hospital, Thailand, and to compare this intake with protein and energy intake as recommended by the physician.

Twenty-eight adult patients (17 men and 11 women) were selected at random from records of medical wards, which included patients with different medical conditions. All patients were over 15 years of age. Only patients on regular and modified diets were included. Data were collected for three meals a day over a period of four weeks. The period of hospitalization ranged from one day to seven days with an average of 4.7 days.

A special sheet was used for each patient to record his daily food intake for three meals. One dietitian performed all the calculation and preparation of food served to patients according to the physician's prescription. Generally the physician prescribed only energy and protein for patients according to age, sex and clinical

* This study was carried out at the Institute of Nutrition, Mahidol University (INMU), Thailand, under the financial support of World Hunger Programme (WHP) of the United Nations University. 
Table 1. Daily mean protein and energy intake of patients compared with physician's prescription.

\begin{tabular}{lccccccc}
\hline & & \multicolumn{2}{c}{ Protein } & & \multicolumn{2}{c}{ Energy } \\
\cline { 3 - 4 } \cline { 6 - 7 } Sex & $\begin{array}{c}\text { No. of } \\
\text { subjects }\end{array}$ & $\begin{array}{c}\text { Intake } \\
(\mathrm{g})\end{array}$ & $\begin{array}{c}\text { \% of physician } \\
\text { prescription }\end{array}$ & & $\begin{array}{c}\text { Intake } \\
(\mathrm{kcal})\end{array}$ & $\begin{array}{c}\% \text { of physician } \\
\text { prescription }\end{array}$ \\
\hline Male & 17 & $45.2 \pm 20.6^{\mathrm{a}}$ & 58.5 & & $1,106.1 \pm 406.1$ & 62.4 \\
Female & 11 & $48.1 \pm 18.7$ & 60.7 & & $1,136.9 \pm 332.9$ & 65.6 \\
Total & 28 & $46.2 \pm 19.3$ & 59.7 & & $1,118.2 \pm 372.8$ & 63.6 \\
\hline
\end{tabular}

${ }^{\mathrm{a}}$ Mean $\pm \mathrm{SD}$.

condition. In this study no attempt was made to record the medical condition of patients or to analyze other nutrients.

After patients had finished eating, the specific trays were taken to the Metabolic Kitchen for the checking and weighing of food wastes. The amount of food wastes were then deducted from the amount of food served, in order to find the actual amount of food consumed by each patient. The intake of protein, fat, carbohydrate and energy was estimated from the weight and number of portions eaten from each food group in the exchange lists (5).

Adequate energy intake is necessary for efficient utilization of protein in the diet. Moreover, it is difficult to assure the nutritional adequacy of diets that are low in energy (6). The daily mean protein and energy intake of patients compared with the physician's prescription is shown in the Table 1 . There was no significant difference in protein and energy intake between male and female patients. If we assume that the patients had eaten only the three meals, the daily mean food intake of these patients would not supply sufficient protein and energy to meet the physician's prescription. However, one limitation of our conclusion is that food eaten in addition to hospital meals were not observed. Patients may have obtained food from the canteen or from visitors, and thus it is difficult to observe accurately the consumption of food by patients between meals during the study period. This is particularly true when medical and paramedical personnel are involved with other work and unable to supervise particular patients for $24 \mathrm{~h}$.

The findings of this study support those of previous ones(2), that more attention should be paid to nutritional management for hospitalized patients in Thailand. The action plan for improvement of malnutrition in hospitalized patients includes: improve the nutrition training of physicians, nurses and other persons involved with nutrition care of patients (4); re-evaluate current practices of nutritional services provided for the patients (4); lay stress on nutritional guidance and education of the patients; and, finally, more emphasise should be given to further studies on the assessment of food intake of hospitalized patients. 


\section{REFERENCES}

1) Bistrain, B. R., Blackburn, G. L., Hallowell, E., and Heddle, R. (1974): Protein status of general surgical patients, $J A M A, \mathbf{2 3 0}, 858-860$.

2) Tanphaichitr, V., Kulapongse, S., and Komindr, S. (1980): Assessment of nutritional status in adult hospitalized patients. Nutr. Metab., 24, 23-31.

3) Bistrain, B. R., Blackburn, G. L., Vitale, J., Cochran, D., and Naylor, J. (1976): Prevalence of malnutrition in general medical patients, JAMA, 235, 1567-1570.

4) Butterworth, C. E. (1974): Malnutrition in the hospital. JAMA, 230, 879.

5) Ohlson, M. A. (1972): Experimental and Therapeutic Dietetics, Burgess Publishing Company, Minneapolis, pp. 1-23.

6) National Academy of Science (1980): Recommended Dietary Allowances, 9th Ed., Washington, D. C., pp. 16-30. 